\title{
Mastomys natalensis Has a Cellular Immune Response Profile Distinct from Laboratory Mice
}

\author{
Tsing-Lee Tang-Huau ${ }^{1, * \mathbb{D}}$, Kyle Rosenke ${ }^{1}$, Kimberly Meade-White ${ }^{1}$, Aaron Carmody ${ }^{2}$, Brian J. Smith ${ }^{3}$, \\ Catharine M. Bosio ${ }^{4}$, Michael A. Jarvis ${ }^{5,6}$ and Heinz Feldmann ${ }^{1, *}$ (i)
}

1 Laboratory of Virology, Division of Intramural Research, National Institute of Allergy and Infectious Diseases, Rocky Mountain Laboratories, National Institute of Health, Hamilton, MT 59840, USA; kyle.rosenke@nih.gov (K.R.); kmeade-white@niaid.nih.gov (K.M.-W.)

2 Research Technologies Branch, Rocky Mountain Laboratories, NIAID, NIH, Hamilton, MT 59840, USA; acarmody@niaid.nih.gov

3 Rocky Mountain Veterinary Branch Division of Intramural Research, National Institute of Allergy and Infectious Diseases, Rocky Mountain Laboratories, National Institute of Health, Hamilton, MT 59840, USA; brian.smith2@nih.gov

4 Laboratory of Bacteriology, Division of Intramural Research, National Institute of Allergy and Infectious Diseases, Rocky Mountain Laboratories, National Institute of Health, Hamilton, MT 59840, USA; bosioc@niaid.nih.gov

5 Faculty of Health: Medicine, Dentistry and Human Sciences, School of Biomedical Sciences, University of Plymouth, PL4 8AA, UK; michael.jarvis@plymouth.ac.uk

6 The Vaccine Group (TVG) Ltd., 14 Research Way, Derriford Research Facility, Plymouth Science Park, Plymouth PL6 8BU, UK

check for updates

Citation: Tang-Huau, T.-L.; Rosenke, K.; Meade-White, K.; Carmody, A.; Smith, B.J.; Bosio, C.M.; Jarvis, M.A.; Feldmann, H. Mastomys natalensis Has a Cellular Immune Response Profile Distinct from Laboratory Mice. Viruses 2021, 13, 729. https:/ / doi.org/10.3390/v13050729

Academic Editors: James Strong and David Safronetz

Received: 22 March 2021

Accepted: 17 April 2021

Published: 22 April 2021

Publisher's Note: MDPI stays neutral with regard to jurisdictional claims in published maps and institutional affiliations.

Copyright: (c) 2021 by the authors. Licensee MDPI, Basel, Switzerland. This article is an open access article distributed under the terms and conditions of the Creative Commons Attribution (CC BY) license (https:/ / creativecommons.org/licenses/by/ $4.0 /)$.
* Correspondence: tsing-lee.tang@nih.gov (T.-L.T.-H.); feldmannh@niaid.nih.gov (H.F.); Tel.: +1-4063757410 (H.F.)

\begin{abstract}
The multimammate mouse (Mastomys natalensis; M. natalensis) has been identified as a major reservoir for multiple human pathogens including Lassa virus (LASV), Leishmania spp., Yersinia spp., and Borrelia spp. Although M. natalensis are related to well-characterized mouse and rat species commonly used in laboratory models, there is an absence of established assays and reagents to study the host immune responses of $M$. natalensis. As a result, there are major limitations to our understanding of immunopathology and mechanisms of immunological pathogen control in this increasingly important rodent species. In the current study, a large panel of commercially available rodent reagents were screened to identify their cross-reactivity with $M$. natalensis. Using these reagents, ex vivo assays were established and optimized to evaluate lymphocyte proliferation and cytokine production by $M$. natalensis lymphocytes. In contrast to C57BL/6J mice, lymphocytes from $M$. natalensis were relatively non-responsive to common stimuli such as phytohaemagglutinin $\mathrm{P}$ and lipopolysaccharide. However, they readily responded to concanavalin A stimulation as indicated by proliferation and cytokine production. In summary, we describe lymphoproliferative and cytokine assays demonstrating that the cellular immune responses in $M$. natalensis to commonly used mitogens differ from a laboratory-bred mouse strain.
\end{abstract}

Keywords: Mastomys natalensis; immune response; T cell; effector cytokines; concanavalin A; phytohaemagglutinin P; lipopolysaccharide; Lassa virus

\section{Introduction}

Mastomys natalensis, a member of the Muridae family [1], has high prevalence across sub-Saharan Africa [2-4]. M. natalensis frequently lives in close association with humans and has been identified as a host reservoir for several zoonotic pathogens, including LASV [5-7], Leishmania major (L. major) [8], Borrelia spp. [9-11], and Yersinia pestis [12]. In contrast to humans, infection of $M$. natalensis by many of these zoonotic pathogens appears to be asymptomatic. How the immune system plays a role in pathogen persistence 
and clearance in these animals is unknown. An improved understanding of mechanisms by which $M$. natalensis controls microbial infection and transmission may lead to the development of novel intervention strategies to reduce zoonotic transmission to humans.

Laboratory mouse and rat models have provided invaluable insight into the pathology and immunobiology of many different pathogens [13-18]. However, it is becoming increasingly appreciated that many aspects of microbial immunobiology may differ in these established rodent models from those of wild rodent species serving as pathogen reservoirs. Further, the applicability of commercially available reagents and well-established immunological techniques, including flow cytometry and in vitro T-cell assays, commonly used to study immune responses in laboratory mice and rats have not been established for the study of $M$. natalensis immunity.

$\mathrm{CD}^{+}$and $\mathrm{CD}^{+}$cytotoxic $\mathrm{T}$ cells play a crucial role in many antimicrobial immune responses via the production of effector cytokines, such as interferon gamma (IFN- $\gamma$ ) and tumor necrosis factor alpha (TNF- $\alpha$ ), leading to eradication and protective immunity against a range of microbial pathogens. Upon activation, naïve $\mathrm{CD}^{+} \mathrm{T}$ cells differentiate into distinct $\mathrm{T}$ cell subsets (Th1, Th2, Th17, Tfh, Treg) based on signals from the antigenic environment and interactions with antigen-presenting cells (APCs) [19]. In response to viral [20-22], parasitic [23-26], or bacterial $[27,28]$ infections, $C D 4^{+} \mathrm{T}$ cells predominantly differentiate into Th1 cells that produce inflammatory cytokines (i.e., IFN- $\gamma$ and TNF- $\alpha$ ) and participate in cell-mediated immune responses, such as enhancement of the differentiation of naïve $\mathrm{CD} 8^{+} \mathrm{T}$ cells into cytotoxic T cells (CTL) for the clearance of infections of viral [20,21,29], bacterial [30-32], and parasitic [33,34] origins. $\mathrm{CD}^{+} \mathrm{T}$ cells can also mediate B cell differentiation and antibody production against extracellular [35-37] and intracellular [38,39] pathogens.

In the present study, we first aimed to determine if conventional reagents used in laboratory rodent studies could be used to trigger $M$. natalensis cells. We screened commercially available antibodies for use with $M$. natalensis splenic lymphocytes. Using identified reagents, we optimized in vitro assays for T-cell proliferation and the detection of IFN- $\gamma$ and TNF- $\alpha$ production. We show that in response to well-defined stimuli, the activation potential of $M$. natalensis splenic lymphocytes differs substantially from those observed in C57BL/6J mice.

\section{Materials and Methods}

\subsection{Animals}

In this study, we used M. natalensis from an in-house breeding colony originally established from rodents captured in Doneguebougou, Mali [40]. C57BL/6J mice were obtained from Jackson Laboratory. For all experiments, we used 5-7 week old animals with equal sex distribution. The number of animals used for each experiment is indicated in the legends of the figures. M. natalensis were free of ectromelia virus, mouse rotavirus, lymphocytic choriomeningitis virus, mouse adenovirus, Sendai virus, mouse hepatitis virus, minute mouse virus, mouse parvovirus, mouse polyoma virus, mouse norovirus, Theiler's murine encephalomyelitis virus, Mycoplasma pulmonis, pinworms, and ectoparasites according to dirty bedding serology and filter EDx PCR testing (IDEXX BioAnalytics, Columbia, $\mathrm{MO}, \mathrm{USA})$. C57BL/6J mice were free of the above pathogens according to vendor reports. Animal studies were approved by the Institutional Animal Care and Use Committee and were conducted in compliance with all institutional and national guidelines for use and handling of animals.

\subsection{Reagents and Antibodies}

A list of reagents and antibodies is provided in Table 1. 
Table 1. List of reagents and antibodies used in this study.

\begin{tabular}{|c|c|c|}
\hline \multicolumn{3}{|l|}{ Mechanical and Tissue Dissociation } \\
\hline Reagents & References & Vendors \\
\hline Gibco Fetal Bovine Serum & 16000044 & ThermoFisher \\
\hline RPMI & R8758 & Sigma-Aldrich \\
\hline Pencillin/Streptomycin & 15070063 & ThermoFisher \\
\hline L-glutamine & 25030164 & ThermoFisher \\
\hline$\beta$-Mercaptoethanol & M3148-25ML & Sigma-Aldrich \\
\hline Miltenyi dissociator $\mathrm{C}$ tubes & 130-096-334 & Miltenyi \\
\hline Cell strainer $(40 \mu \mathrm{m})$ & 22-363-547 & Fisherscientific \\
\hline Red blood cell lysis ( $1 \times$ RBC Lysis Buffer) & $00-4333-57$ & ThermoFisher \\
\hline \multicolumn{3}{|c|}{ In vitro Lymphocytes stimulation and proliferation } \\
\hline Reagents & References & Vendors \\
\hline Concanavalin A & 00-4978-03 & ThermoFisher \\
\hline Phytohaemagglutinin P & 10576015 & ThermoFisher \\
\hline Lipopolysaccharide & L2630-10MG & Sigma-Aldrich \\
\hline Mouse interleukin (IL)-2 & $130-120-331$ & Miltenyi \\
\hline CellTrace Violet & C34557 & ThermoFisher \\
\hline \multicolumn{3}{|l|}{ Reagents and antibodies for flow cytometry } \\
\hline Reagents & References & Vendors \\
\hline Phorbol 12-myristate 13-acetate & P8139-1MG & Sigma-Aldrich \\
\hline Ionomycin & 407950-1MG & Merck Calbiochem \\
\hline Brefeldin A & 00-4506-51 & ThermoFisher \\
\hline TruStain FcX & 101320 & BioLegend \\
\hline Fixable Viability Dye eFluor ${ }^{\mathrm{TM}} 780$ & $65-0865-14$ & ThermoFisher \\
\hline $\begin{array}{c}\text { Intracellular Fixation \& Permeabilization } \\
\text { Buffer Set }\end{array}$ & $88-8824-00$ & ThermoFisher \\
\hline Rat anti Human CD3 FITC & MCA1477F & Bio-Rad \\
\hline Anti-mouse TNF- $\alpha$ Brilliant Violet 785 & 506341 & BioLegend \\
\hline Mouse Anti-Rat IFN- $\gamma$ PE & 559499 & BDbiosciences \\
\hline
\end{tabular}

\subsection{Tissue Preparation}

Spleens were harvested and placed in RPMI supplemented with 10\% FBS and 2\% of penicillin/streptomycin (ThermoFisher, Carlsbad, CA, USA), L-glutamine (Sigma, St. Louis, MO, USA), and $0.5 \mathrm{mM}$ of $\beta$-2-mercaptoethanol (Sigma, St. Louis, MO, USA) (cRPMI). Tissues were individually dissociated at room temperature (RT) in Miltenyi dissociator C tubes (Miltenyi Biotec, San Diego, CA, USA) (Table 1). Following dissociation, spleen homogenates were passed through a cell strainer (Fisher Scientific, Pennsylvania, PA, USA) and centrifuged at $700 \times g$ for $5 \mathrm{~min}$. Red blood cell were lysed using $1 \times$ RBC Lysis Buffer according to manufacturer's instructions (eBioscience ${ }^{\mathrm{TM}}$ ThermoFisher, Carlsbad, CA, USA). Remaining cells were washed and resuspended in cRPMI, and cell counts were performed by mixing $10 \mu \mathrm{L}$ of sample with $10 \mu \mathrm{L}$ of $0.4 \%$ trypan blue solution. The mixture was loaded onto a chamber slide and counted using a Countess cell counter (Bio-Rad, Hercules, CA, USA).

\subsection{T Cell Proliferation}

To analyze T cell proliferation, splenocytes were stained with CellTrace Violet (CTV, ThermoFisher, Carlsbad, CA, USA) prior to stimulation with mitogens. Splenocytes $\left(5 \times 10^{5}\right.$ cells/96-well round bottom plate) were added to triplicate wells and stimulated with three different mitogens: concanavalin A (ConA; $1 \times$ ThermoFisher, Carlsbad, CA, USA), phytohaemagglutinin P (PHA; 1.5\%, ThermoFisher, Carlsbad, CA, USA), and lipopolysaccharide (LPS; $10 \mu \mathrm{g} / \mathrm{mL}$, Sigma, St. Louis, MO, USA). Mitogen stimulation was performed either in the presence or absence of mouse interleukin (IL)-2 (25 IU / mL; Miltenyi, San Diego, CA, USA) for up to 6 days in cRPMI at $37^{\circ} \mathrm{C}, 5 \% \mathrm{CO}_{2}$ (Table 1 ). 


\subsection{Extracellular Staining for Flow Cytometry}

Non-specific binding was blocked using TruStain (Biolegend, San Diego, CA, USA) for $10 \mathrm{~min}$. Splenocytes were stained with T cell surface markers with rat anti-CD3, CD8, and CD4 for $30 \mathrm{~min}$ at $4{ }^{\circ} \mathrm{C}$ (Table 1). The samples were analyzed on a BD FACS Symphony instrument (BD Biosciences, San Jose, CA, USA) and analyzed by FlowJo v10.

\subsection{Intracellular Staining for Flow Cytometry}

T cells were re-stimulated on day 6 with phorbol 12-myristate 13-acetate (PMA, $50 \mathrm{ng} \mathrm{mL}$, Sigma) and ionomycin (Iono; $1 \mu \mathrm{g} / \mathrm{mL}$; Merck Calbiochem, Burlington, MA, USA) for $6 \mathrm{~h}$ in the presence of brefeldin A (BFA; $1 \times$; eBioscience ThermoFisher, Carlsbad, $\mathrm{CA}, \mathrm{USA}$ ) at $37^{\circ} \mathrm{C}, 5 \% \mathrm{CO}_{2}$. Non-specific binding was blocked using TruStain (Biolegend, San Diego, CA, USA) for $10 \mathrm{~min}$. Cell viability was assessed using live/dead eFluor780 (ThermoFisher, Carlsbad, CA, USA) for $20 \mathrm{~min}$ at $4{ }^{\circ} \mathrm{C}$ (Table 1). Then the cells were fixed and permeabilized (Intracellular Fixation \& Permeabilization Buffer Set; ThermoFisher, Carlsbad, CA, USA) and stained for rat anti-CD3, a cytoplasmic epitope of CD3 (Bio-Rad, Hercules, CA, USA) and selected intracellular proteins (anti-mouse TNF- $\alpha$; anti-rat IFN- $\gamma$ ) (Table 1), for 45min at RT in permeabilization wash buffer (eBioscience ThermoFisher, Carlsbad, CA, USA). The samples were analyzed using the BD FACS Symphony instrument (BD Biosciences, San Jose, CA, USA) and FlowJo v10.

\subsection{Cytometric Bead Array (CBA)}

Splenocytes $\left(1 \times 10^{6}\right.$ cells/well) were incubated with or without ConA, LPS, or PHA mitogens for $24 \mathrm{~h}$ in cRPMI as technical duplicate replicates. Supernatants were collected and stored at $-20{ }^{\circ} \mathrm{C}$ until use. TNF- $\alpha$ and IFN- $\gamma$ release into the supernatant was measured by CBA using anti-mouse TNF- $\alpha$ and anti-rat IFN- $\gamma$ antibodies according to the manufacturer's instructions (Table 2).

Table 2. Commercial kits used for the detection of cytokines produced by Mastomys-derived splenic lymphocytes.

\begin{tabular}{|c|c|c|c|c|}
\hline & Reagents & Source & Catalog Number & $\begin{array}{c}\text { Cross-React with } \\
\text { Mastomys }\end{array}$ \\
\hline \multirow{3}{*}{$\begin{array}{c}\text { Cytometric Bead } \\
\text { Array (CBA) }\end{array}$} & Rat IFN- $\gamma$ FlexSet & BD & 558305 & Yes \\
\hline & Mouse TNF- $\alpha$ Flex Set & BD & 558299 & Yes \\
\hline & $\begin{array}{c}\text { Mouse/Rat } \\
\text { Soluble Protein Master Buffer Kit }\end{array}$ & BD & 558266 & Yes \\
\hline \multirow[b]{2}{*}{ ELISPOT } & Rat IFN- $\gamma$ Single color & ImmunoSpot & & No \\
\hline & Mouse TNF- $\alpha$ Single color & ImmunoSpot & & Yes \\
\hline \multirow{7}{*}{ ELISA } & Mouse TNF- $\alpha$ ELISA & BioLegend & 430901 & No \\
\hline & Mouse IFN- $\gamma$ ELISA & & & \\
\hline & MAX ${ }^{\mathrm{TM}}$ Standard Set & BioLegend & 430801 & No \\
\hline & Purified Rat Anti-Mouse IFN- $\gamma$ & $\mathrm{BD}$ & 551309 & No \\
\hline & Biotin Anti-Mouse IFN- $\gamma$ & $\mathrm{BD}$ & 551506 & No \\
\hline & Biotin Rat Anti-Mouse IFN- $\gamma$ & $\mathrm{BD}$ & 554410 & No \\
\hline & Recombinant Rat IFN- $\gamma$ & $\mathrm{BD}$ & 550072 & No \\
\hline
\end{tabular}

\subsection{Software and Statistical Analysis}

Flow cytometry data were analyzed using FlowJo software v10 (Tree Star). Statistical analyses were performed using the Prism software v8 (GraphPad, San Diego, CA, USA). Wilcoxon non-parametric test and one-way ANOVA were used. Variance was similar between the groups being compared. 


\section{Results}

3.1. Commercial Rat and Mouse Antibodies Cross-React with M. natalensis T Cell Receptors and Intracellular Cytokines

Commercial rat and mouse antibodies against $\mathrm{T}$ cell receptors (CD3, CD8, CD4) and effector molecules (TNF- $\alpha$ and IFN- $\gamma$ ) were evaluated for their cross-reactivity with M. natalensis splenocytes (Table 3). Spleens from M. natalensis were harvested and stained with $\mathrm{T}$ cell receptor antibodies from different clones and analyzed by flow cytometry. We found that $M$. natalensis $\mathrm{CD} 3$ and $\mathrm{CD} 8 \mathrm{~b}$ receptors were recognized by rat anti-CD3 clone CD3-12 and rat anti-CD8b clone 341, respectively. No CD4 antibodies tested in this study cross-reacted with $M$. natalensis splenocytes (Table 3). In addition, we could demonstrate that $M$. natalensis IFN- $\gamma$ and TNF- $\alpha$ cytokines were recognized by rat anti- IFN- $\gamma$, clone DB-1, and mouse anti- TNF- $\alpha$ clone MP6-XT22, respectively (Table 3).

Table 3. Antibodies tested in this study.

\begin{tabular}{|c|c|c|c|c|c|c|}
\hline Specificity & Antibody & Conjugate & Clone & Reference & Vendor & $\begin{array}{l}\text { Cross-React with } \\
\text { Mastomys }\end{array}$ \\
\hline \multirow{6}{*}{ Mouse } & $\begin{array}{c}\text { Purified } \\
\text { anti-mouse CD4 }\end{array}$ & $\mathrm{N} / \mathrm{A}$ & GK1.5 & 100401 & Biolegend & No \\
\hline & CD3e & PE & $145-2 \mathrm{C} 11$ & 100307 & Biolegend & No \\
\hline & CD8a & $\mathrm{APC}$ & 53.6 .7 & 100711 & Biolegend & No \\
\hline & IFN- $\gamma$ & APC & XMG1.2 & 505809 & Biolegend & No \\
\hline & TNF- $\alpha$ & $\begin{array}{c}\text { Brilliant Violet } \\
785\end{array}$ & MP6-XT22 & 506341 & Biolegend & Yes \\
\hline & TNF- $\alpha$ & PE & MP6-XT22 & 12-7321-41 & eBioscience & Yes \\
\hline $\begin{array}{l}\text { Rat/Human/ } \\
\text { Mouse }\end{array}$ & CD3 & FITC & CD3-12 & MCA1477F & Bio-Rad & Yes \\
\hline \multirow[t]{13}{*}{ Rat } & $\mathrm{CD} 3$ & FITC & G4.18 & 559975 & $\mathrm{BD}$ & No \\
\hline & $\begin{array}{l}\text { Purified anti-rat } \\
\text { CD8b }\end{array}$ & N/A & 341 & 200702 & Biolegend & Yes \\
\hline & CD $8 b$ & PE & eBio341 & $12-0080-82$ & ThermoFisher & No \\
\hline & CD8a & $\mathrm{APC}$ & G28 & 200609 & Biolegend & No \\
\hline & CD8a & BV421 & OX-8 & 740041 & BD & No \\
\hline & $\mathrm{CD} 8 \mathrm{~b}$ & BV421 & 341 & 742915 & $\mathrm{BD}$ & No \\
\hline & $\begin{array}{l}\text { Purified anti-rat } \\
\text { CD8a }\end{array}$ & $\mathrm{N} / \mathrm{A}$ & OX-8 & 201701 & Biolegend & No \\
\hline & $\begin{array}{c}\text { Purified anti-rat } \\
\text { CD4 }\end{array}$ & $\mathrm{N} / \mathrm{A}$ & W3/25 & 201501 & Biolegend & No \\
\hline & CD4 & BV786 & OX-35 & 740912 & $\mathrm{BD}$ & No \\
\hline & $\mathrm{CD} 4$ & BV786 & OX-38 & 743093 & $\mathrm{BD}$ & No \\
\hline & CD4 & $\mathrm{APC}$ & W3/25 & 201509 & Biolegend & No \\
\hline & IFN- $\gamma$ & AF647 & DB-1 & 562213 & BD & Yes \\
\hline & IFN- $\gamma$ & PE & DB-1 & 559499 & BD & Yes \\
\hline Rat/mouse/rabbit & TNF- $\alpha$ & PE & TN3-19.12 & 559503 & $\mathrm{BD}$ & No \\
\hline
\end{tabular}

Note: antibodies that recognized $M$. natalensis are highlighted in bold.

\subsection{ConA Mitogen Efficiently Induced M. natalensis T Cell Proliferation In Vitro}

ConA [41,42], PHA [43-45], and LPS [46,47] are the most commonly used mitogens targeting lymphocytes as they do not require antigen presentation to activate $\mathrm{T}$ cells and have been used to describe general immune responses, such as proliferation and cytokine production, in these cell populations. To optimize the in vitro assay for the induction of $\mathrm{T}$ cell proliferation and differentiation into mature effector cells, spleens from M. natalensis were harvested and stimulated with these three mitogens and $\mathrm{T}$ cell proliferation was measured at different time points $(0,3,4,5$, and 6 days) post-stimulation. Recombinant mouse IL-2 was added to a subset of these samples to assess the impact of IL-2 signaling on activated cell survival, which by itself failed to stimulate T-cell proliferation. The CTV- 
based assay has been used to quantify T-cell proliferation in response to different mitogens. Unstimulated splenocytes were used as negative controls.

In agreement with previous studies, LPS, ConA, and PHA mitogens induced proliferation among C57BL/6J splenic lymphocytes [42,43,47] independently of IL-2 (Figure 1a-c). In contrast to C57BL/6J, M. natalensis splenic lymphocytes stimulated with LPS did not proliferate with or without IL-2 (Figure 1a). We observed that M. natalensis cells stimulated with PHA proliferate only in the presence of recombinant mouse IL-2 (Figure 1b). Finally, ConA was sufficient to enhance a strong $\mathrm{CD}^{+}-\mathrm{T}$ cell proliferation in both $\mathrm{C} 57 \mathrm{BL} / 6 \mathrm{~J}$ and M. natalensis, and this effect was independent of IL-2 (Figure 1c). Thus, ConA triggered the most efficient proliferation of $M$. natalensis $\mathrm{CD}^{+} \mathrm{T}$ cells compared to PHA and LPS mitogens.

\subsection{Comparative Secretion of Effector Molecules in M. natalensis in Response to Stimuli}

To further examine the differential immune response profiles by M. natalensis splenic lymphocytes, we assessed the level of cytokines in cell supernatant or secreting cells following mitogenic stimulation. M. natalensis splenic lymphocytes were stimulated with LPS, PHA, or ConA for $24 \mathrm{~h}$. C57BL/6J splenic lymphocytes were used as a positive control. As described above, the presence of IL-2 can have an impact on T cell proliferation (Figure 1b); therefore, we also included recombinant mouse IL-2 to a subset of samples to determine its impact on cytokine production. TNF- $\alpha$ and IFN- $\gamma$ were detectable in the supernatant of secreting splenic lymphocytes from C57BL/6J mice when stimulated with mitogens as determined by mouse specific ELISA, CBA, and ELISpot kits. No detectable TNF- $\alpha$ and IFN- $\gamma$ in cell culture supernatants from $M$. natalensis splenic lymphocytes was observed when assessed by ELISA (data not shown). However, both cytokines were detected in supernatant utilizing CBA (Table 2). Further, TNF- $\alpha$ was readily detected by ELISpot (Table 2).

We used CBA specific to rat or mouse to measure cytokine responses to different stimuli in M. natalensis and C57BL/6J rodents, respectively. C57BL/6J splenic lymphocytes responded to all stimuli, LPS and ConA, as indicated by the production of both TNF- $\alpha$ and IFN- $\gamma$, and no differences were observed in IL-2 treated groups. Among PHA-stimulated C57BL/6J cells, the production of both cytokines significantly decreased $(p<0.01)$ in the presence of IL-2 (Figure 2a). In contrast, IL-2 did not impact C57BL/6J T-cell proliferation (Figure $1 \mathrm{a}-\mathrm{c}$ ) and M. natalensis stimulated cells only produce TNF- $\alpha$ in response to PHA but not IFN- $\gamma$ independent of the presence of IL-2 (Figure 2b). However, LPS and ConA treatment significantly increased the secretion of TNF- $\alpha$ and IFN- $\gamma$ within $24 \mathrm{~h}$ by M. natalensis splenic lymphocyte. Addition of IL-2 did not significantly change the amount of either cytokine produced under these conditions (Figure 2a,c). Taken together, LPS and ConA efficiently induce both IFN- $\gamma$ and TNF- $\alpha$ secretion independently of IL- 2 in both C57BL/6J and M. natalensis. 

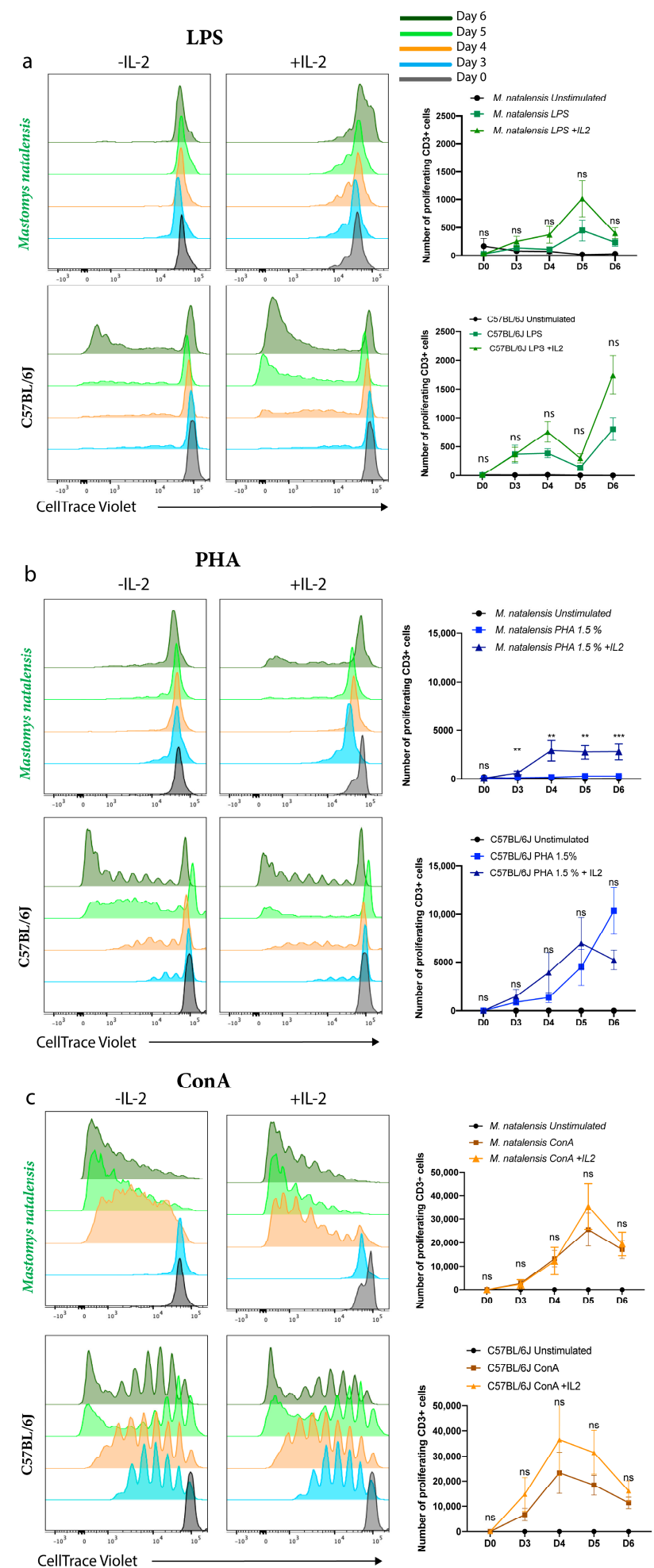

Figure 1. T cell proliferation in response to different stimuli. Splenic cells derived from M. natalensis $(\mathrm{N}=12)$ or C57BL/6J $(\mathrm{N}=12)$ were stimulated with LPS (a), PHA (b), and ConA (c) mitogens in the presence or absence of IL-2 cytokines. A CTV-based assay has been used to quantify T-cell proliferation at different time points. Number of proliferating $\mathrm{CD}^{+} \mathrm{T}$ cells of $\mathrm{M}$. natalensis and C57BL/6J are shown in the upper and bottom graph of parts $\mathrm{a}, \mathrm{b}$, and c, respectively. Mean \pm SEM of three independent experiments. ns: not significant; ${ }^{* *} p<0.01$; ${ }^{* * *} p<0.001$; Wilcoxon nonparametric test. 


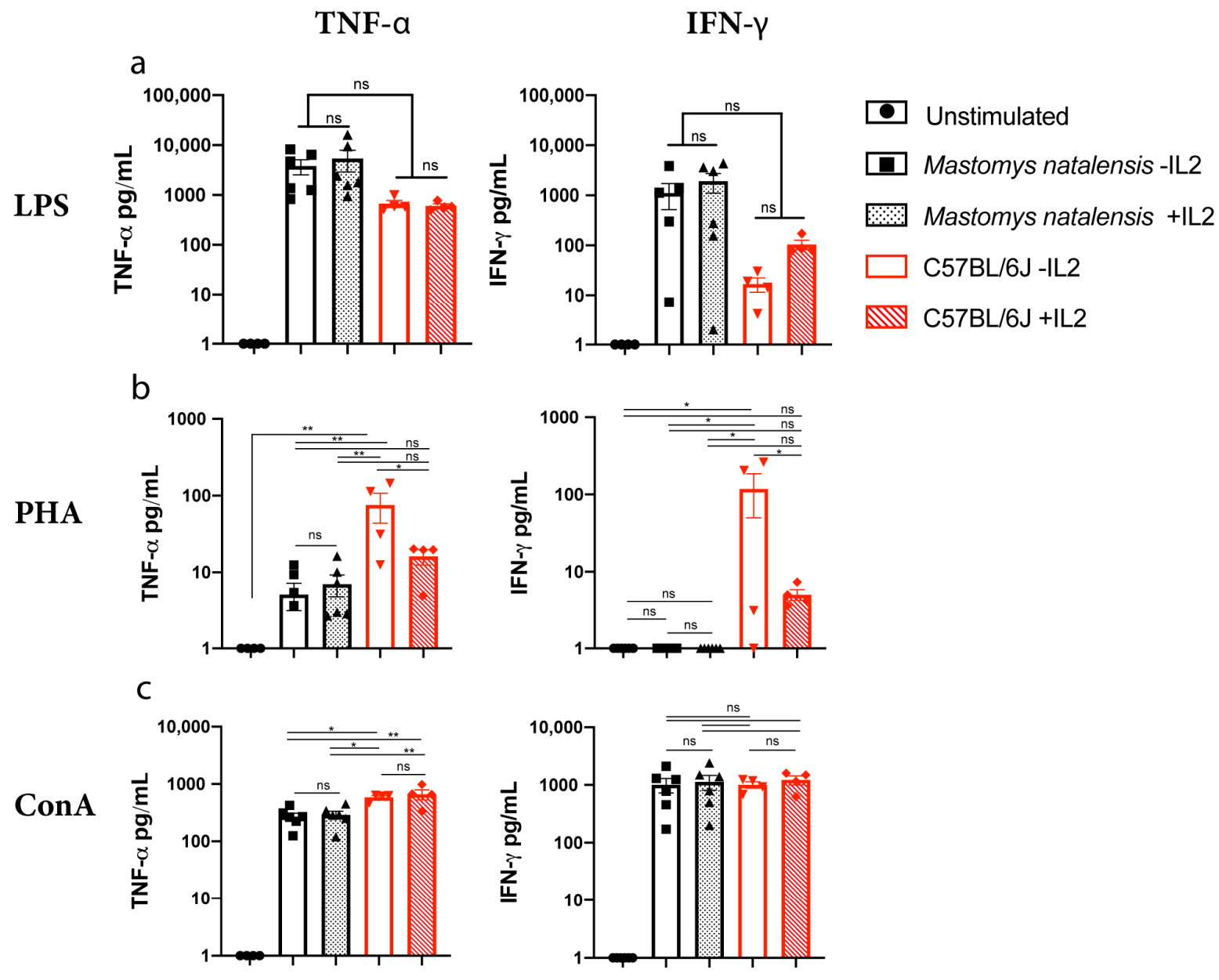

Figure 2. Secretion of effector molecules in response to stimuli. Splenic cells derived from $M$. natalensis $(\mathrm{N}=6)$ or $\mathrm{C} 57 \mathrm{BL} / 6 \mathrm{~J}$ $(\mathrm{N}=4)$. Mice were stimulated with LPS (a), PHA (b), or ConA (c) for $24 \mathrm{~h}$. Secretion of IFN- $\gamma$ and TNF- $\alpha(\mathbf{a}-\mathbf{c})$ were measured in the supernatants by CBA. Symbols represent individual animals. Mean \pm SEM is shown. ns: not significant; ${ }^{*} p<0.01 ;{ }^{* *} p<0.001$; One-way ANOVA.

3.4. Comparative Expression of Intracellular Cytokines in M. natalensis in Response to Different Stimuli

Next, we assessed the expression of effector molecules by $M$. natalensis $\mathrm{CD}^{+} \mathrm{T}$ cells in response to mitogens stimuli. Intracellular IFN- $\gamma$ and TNF- $\alpha$ were not detected among M. natalensis splenic lymphocytes stimulated only with PMA/Iono in the presence of BFA for $6 \mathrm{~h}$. Therefore, M. natalensis splenocytes were stimulated with ConA, LPS, or PHA for 6 days followed by re-stimulation with PMA/Iono in the presence of BFA (Figure 3b). All mitogens induced the expression of both IFN- $\gamma$ and TNF- $\alpha$ among positive control C57BL/6J CD3 ${ }^{+} \mathrm{T}$ cells (Figure 3b,d). All three mitogens also induced the expression of TNF- $\alpha$ by $M$. natalensis $\mathrm{CD}^{+}$T cells, but only ConA induced significant expression of both IFN- $\gamma$ and TNF- $\alpha$ (Figure $3 b, c)$. Notably, as observed in studies assessing the proliferation potential, IL-2 did not impact the expression of either IFN- $\gamma$ or TNF- $\alpha$ in the M. natalensis $\mathrm{CD}^{+}$cell population. Therefore, only ConA efficiently induced the expression of IFN- $\gamma$ and TNF- $\alpha$ by $M$. natalensis $\mathrm{CD}^{+} \mathrm{T}$ cells as detected by intracellular cytokine staining. 
a
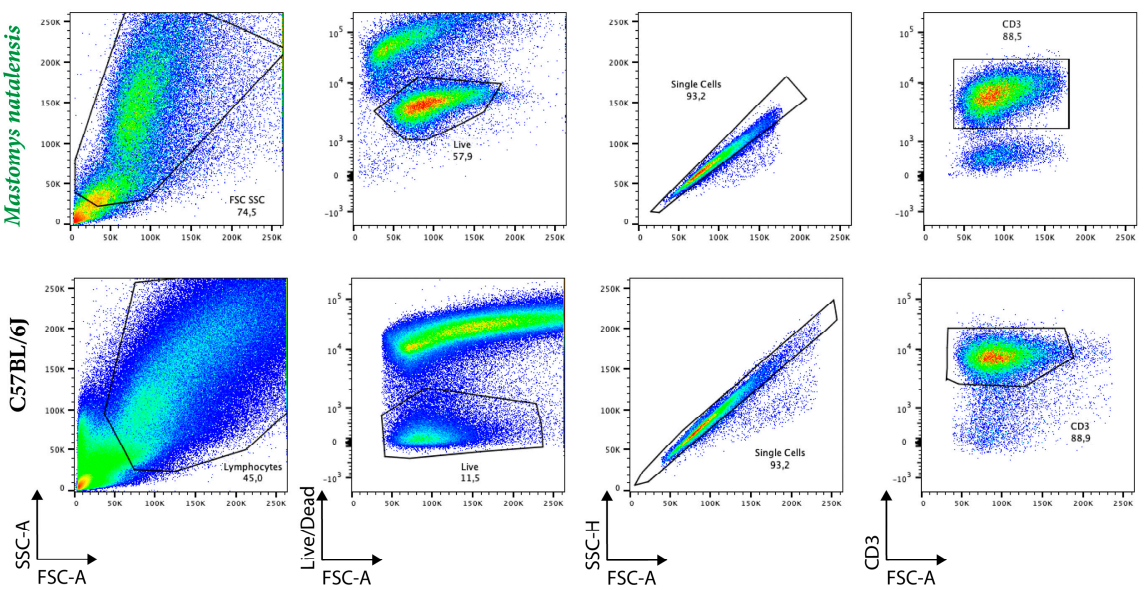

b

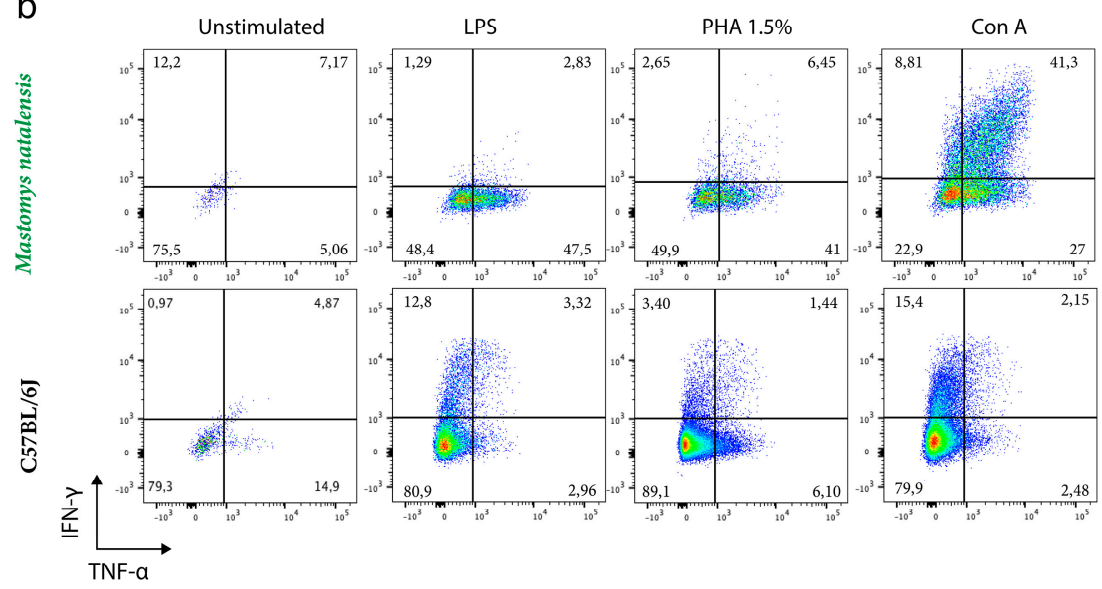

(c)
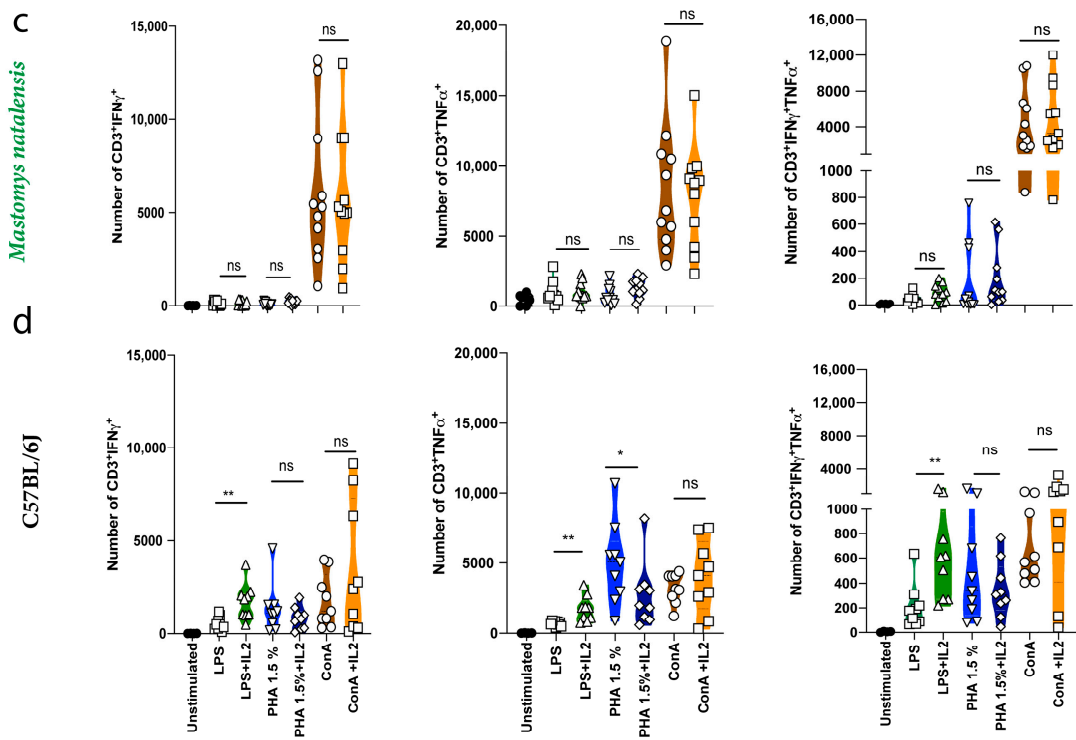

Figure 3. Expression of intracellular cytokines in response to different stimuli. Exemplary gating strategies defining the investigated $\mathrm{CD}^{+} \mathrm{T}$ cell population of $M$. natalensis and C57BL/6J are shown in the upper and bottom portion of graph a, respectively (a); Representative flow cytometry plots of splenic cells derived from $M$. natalensis (upper part) or C57BL/6J mice (bottom part, used as a positive control) stimulated with LPS, PHA, or ConA for 6 days followed by 6 h stimulation with PMA/Ionomycin and BFA (b); Expression of TNF- $\alpha$ and IFN- $\gamma$ were assessed by intracellular staining (b); Number of $\mathrm{CD}^{+} \mathrm{T}$ cells expressing effector molecules by M. natalensis (c); and C57BL/6J (d) is shown. Symbols represent individual animal. $\mathrm{N}=12 \mathrm{M}$. natalensis and $\mathrm{N}=9 \mathrm{C} 57 \mathrm{BL} / 6 \mathrm{~J}$ mice of two independent experiments (c,d). ns: not significant; ${ }^{*} p<0.01 ;{ }^{* *} p<0.001$; One-way ANOVA. 


\section{Discussion}

M. natalensis is a host for multiple emerging and re-emerging human pathogens (i.e., LASV, Leishmania spp., Yersinia spp., and Borrelia spp.). It is unknown how these rodents survive infection with these pathogens to serve as vectors for transmission to humans. Understanding this paradigm may ultimately help the development of new therapeutic strategies. T cells play an important role in the defense against microorganisms, in part by secreting key mediators which enable eradication of the infecting agent. Th1 $\mathrm{T}$ cells are characterized by their property to produce IFN- $\gamma$, TNF- $\alpha$, and IL-2. These cells play a central role in mediating adaptive immune responses to microbial agents $[21,23,32,33,35,48,49]$, tumor [50], inflammation, and autoimmune diseases [51,52]. Therefore, development of assays that assess these responses in $M$. natalensis-derived cells would provide valuable insight into our understanding of ongoing immune responses in this reservoir host.

To study the T cell-mediated immunity in M. natalensis, we identified, optimized, and established immunological techniques used for laboratory mice and rats to trigger $\mathrm{T}$ cell activation. M. natalensis splenocytes were stimulated with the classical mitogens (LPS, PHA, or ConA) that do not rely on antigen specificity or presentation to trigger proliferation and production of cytokines by these cells [41-47]. We found that M. natalensis CD3 ${ }^{+}$, $\mathrm{CD} 8^{+} \mathrm{T}$ cell markers, and IFN- $\gamma$ were largely recognized by antibodies directed against rat proteins whereas TNF- $\alpha$ was detected by antibodies targeting mouse cytokines (Table 3). Approaches for measuring cytokines/chemokines associated with cytotoxic T-lymphocyte function in response to mitogenic stimuli in cell supernatant or cytokine-secreting cells were also assessed. We found that only CBA, a bead-based immunoassay, was capable of measuring both $M$. natalensis IFN- $\gamma$ and TNF- $\alpha$ in cell culture supernatants after $24 \mathrm{~h}$ of stimulation with mitogens (Figure 2). CBA, ELISA, and ELISpot assays all use primary (capture) and secondary (detection) antibodies. However, there are differences among these methods, such as their sensitivity to detect low frequency of cytokine-secreting cells (ELISpot) or cytokines release into cell culture (CBA and ELISA) [53-55]. In addition, we have demonstrated that $M$. natalensis IFN- $\gamma$ is only detectable by a rat-IFN- $\gamma$ CBA kit and TNF- $\alpha$ by mouse- TNF- $\alpha$ ELISpot and CBA kits. These results suggest that paired antibodies used to detect IFN- $\gamma$ or TNF- $\alpha$ may differ in those assays or that some antibodies do not function due to lack of binding. This is supported by a recent phylogenetic study demonstrating that the genome of Mastomys coucha aligns to $90.1 \%$ with mouse and $85.5 \%$ with rat, supporting an intermediate position of M. natalensis in the rodent taxonomy [56].

In this study, we have demonstrated significant differences in $\mathrm{T}$ cell proliferation and cytokine production between $M$. natalensis and C57BL/6J splenic lymphocytes in response to different stimuli. It should be noted, however, that $M$. natalensis animals from our colony were recently derived from wild caught animals [40] and thus may harbor microorganisms distinct from laboratory C57BL/6 mice derived from a clean and defined laboratory environment. Therefore, $M$. natalensis immune responses to experimental mitogen stimulation may be reduced due to continuing exposure to microbial stimuli $[57,58]$.While all mitogens induced C57BL/6J splenic lymphocytes proliferation, independent of IL-2, LPS was not effective at triggering proliferation of $M$. natalensis splenic $T$ cells regardless of whether exogenous IL-2 was present or not (Figure 1a). Numerous studies using mouse and human cells have investigated the effect of LPS on cell proliferation [59] and cytokine production by lymphocytes [60]. LPS has been noted to both activate [61] and inhibit [62] lymphocytic activation. However, most of the studies have shown that the mechanism of T cell activation by LPS is mediated by innate cells, such as monocytes or APCs, providing costimulatory molecules signals via direct cell contact $[61,63]$. Therefore, our results suggested that LPS may not trigger appropriate responses by M. natalensis APCs that support $\mathrm{T}$ cell proliferation in our model. However, the lack of specific antibodies and immunology tools to M. natalensis currently does not allow us to confirm the role of LPS on M. natalensis APCs or T cells. In contrast, M. natalensis splenic lymphocytes stimulated with LPS for $24 \mathrm{~h}$ increased secretion of TNF- $\alpha$ and IFN- $\gamma$ which was also independent of IL-2 (Figure 2a). This may be explained in part by differences of transcription, translation, 
protein processing, export, and protein degradation by each species of rodent [64]. Guy et al. also demonstrated that the large number of immunoreceptor tyrosine activation motifs (ITAM) within the T cell receptor (TCR)-CD3 complex (TCR-CD3 ITAM) play an important role in $\mathrm{T}$ cell development and function. Indeed, they have shown that low CD3 ITAM engage TCR-driven pathways that lead to cytokine production while high TCR-CD3 ITAM multiplicity promote $\mathrm{T}$ cell proliferation. These results support that proliferation and cytokine production can be two distinct events in T cells, dependent on the TCR signaling [65].

We also demonstrated that $M$. natalensis splenocytes stimulated with PHA require the presence of IL-2 to proliferate, while PHA efficiently induce C57BL/6J splenic lymphocytes proliferation without IL-2 cytokine (Figure 1b). Regardless of the presence/absence of IL-2, PHA was efficient to induce secretion of TNF- $\alpha$ but not IFN- $\gamma$ by M. natalensis $\mathrm{CD}^{+} \mathrm{T}$ cells. However, IL-2 significantly decreased the production of both cytokines by C57BL/6J cells (Figure $2 \mathrm{~b}$ ). The decrease of IFN- $\gamma$ and TNF- $\alpha$ secretion by C57BL/6J splenic lymphocytes stimulated with PHA in the presence of IL-2 suggests that exogenously added IL-2 may have induced $\mathrm{T}$ cell exhaustion resulting in functional impairment of $\mathrm{T}$ cells to secrete IFN- $\gamma$ and TNF- $\alpha$. Further studies need to confirm this hypothesis. We hypothesize that PHA combined with IL-2 may induce IL-2 receptor expression by T cells [45], resulting in enhanced proliferation by $M$. natalensis cells. However, lack of specific antibodies against $M$. natalensis do not allow us to confirm the effect of PHA on IL-2 receptor at this time. Finally, we demonstrated that ConA was sufficient to stimulate M. natalensis T cell proliferation and differentiation into effector T cells in the absence of IL-2 (Figures 1 and 3) and significantly increased the secretion of TNF- $\alpha$ and IFN- $\gamma$ from M. natalensis splenic lymphocytes independent of the presence or absence of IL-2 (Figure 2c). This suggests that ConA by itself triggered cross-linking of the TCR complex which leads to T cell proliferation and cytokine secretion among $M$. natalensis splenic cells, contrary to LPS and PHA mitogens [42]. Still, the molecular mechanisms by which TNF- $\alpha$ and IFN- $\gamma$ genes expression and secretion occurs in response to each mitogen remain to be elucidated.

\section{Conclusions}

To conclude, only ConA was a strong stimulator of proliferation and differentiation into effector cells of $M$. natalensis $\mathrm{CD}^{+} \mathrm{T}$ cells. Thus, ConA-stimulating assays will allow us to determine ranges for IFN- $\gamma$ and TNF- $\alpha$ in response to mitogen stimulation for $M$. natalensis-derived cells by flow cytometry (intracellular staining and CBA). These assays will be used to characterize the immune response in $M$. natalensis against infection and we believe this understanding of differences in distinct immune responses provides a critical underpinning for future studies on the immune response to pathogen infection in an increasingly important reservoir species. This is an important first step in the development of assays designed to understand the role of the innate and adaptive immune responses in this important reservoir species. Moving forward, there is a need to identify and optimize more immunology tools for M. natalensis, such as assays assessing cytotoxicity of CD4/CD8 $\mathrm{T}$ cells in vivo and in vitro.

Author Contributions: T.-L.T.-H. and H.F. designed experiments. T.-L.T.-H. conducted and performed all the assays and analyzed all data using the Prism software v8 (GraphPad). B.J.S. and K.M.-W. and K.R. performed the necropsies. A.C. performed flow analysis for CBA assays. T.-L.T.-H., C.M.B., M.A.J., and H.F. wrote the initial draft with the other authors providing editorial comments. H.F. supervised the project. All authors have read and agreed to the published version of the manuscript.

Funding: This research was funded by the Division of Intramural Research, National Institute of Allergy and Infectious Diseases and MAJ is funded through The Vaccine Group Ltd., and the University of Plymouth.

Institutional Review Board Statement: The study was conducted according to the guidelines of the Declaration of Helsinki, and approved by the Institutional Animal Care and Use Committee and 
were conducted in compliance with all institutional and national guidelines for use and handling of animals (protocol code 2019-043 and approved in 2019).

Informed Consent Statement: Not applicable.

Data Availability Statement: The data presented in this study are available on request f, rom the corresponding author.

Acknowledgments: We thank Shelly J. Robertson for providing C57BL/6J mice and Ronald Messer for sharing mouse antibodies.

Conflicts of Interest: The authors declare no conflict of interest identified for any individual involved in the study. The opinions, conclusions and recommendations in this report are those of the authors and do not necessarily represent the official positions of the National Institute of Allergy and Infectious Diseases (NIAID) at the National Institutes of Health (NIH). There were no conflict of interests.

\section{References}

1. Hasche, D.; Rösl, F. Mastomys Species as Model Systems for Infectious Diseases. Viruses 2019, 11, 182. [CrossRef]

2. Jansa, S.A.; Giarla, T.C.; Lim, B.K. The Phylogenetic Position of the Rodent GenusTyphlomysand the Geographic Origin of Muroidea. J. Mammal. 2009, 90, 1083-1094. [CrossRef]

3. Lecompte, E.; Granjon, L.; Denys, C. The phylogeny of the Praomys complex (Rodentia: Muridae) and its phylogeographic implications. J. Zool. Syst. Evol. Res. 2002, 40, 8-25. [CrossRef]

4. Chevret, P.; Granjon, L.; Duplantier, J.-M.; Denys, C.; Catzeflis, F.M. Molecular phylogeny of the Praomys complex (Rodentia: Murinae): A study based on DNA/DNA hybridization experiments. Zool. J. Linn. Soc. 1994, 112, 425-442. [CrossRef]

5. Walker, D.H.; Wulff, H.; Lange, J.V.; Murphy, F.A. Comparative pathology of Lassa virus infection in monkeys, guinea-pigs, and Mastomys natalensis. Bull. World Health Organ. 1975, 52, 523-534. [PubMed]

6. Olayemi, A.; Cadar, D.; Magassouba, N.; Obadare, A.; Kourouma, F.; Oyeyiola, A.; Fasogbon, S.; Igbokwe, J.; Rieger, T.; Bockholt, S.; et al. New Hosts of The Lassa Virus. Sci. Rep. 2016, 6, 25280. [CrossRef]

7. Monath, T.P.; Newhouse, V.F.; Kemp, G.E.; Setzer, H.W.; Cacciapuoti, A. Lassa Virus Isolation from Mastomys natalensis Rodents during an Epidemic in Sierra Leone. Science 1974, 185, 263-265. [CrossRef]

8. Sadlova, J.; Vojtkova, B.; Hrncirova, K.; Lestinova, T.; Spitzova, T.; Becvar, T.; Votypka, J.; Bates, P.; Volf, P. Host competence of African rodents Arvicanthis neumanni, A. niloticus and Mastomys natalensis for Leishmania major. Int. J. Parasitol. Parasites Wildl. 2019, 8, 118-126. [CrossRef]

9. Boardman, K.; Rosenke, K.; Safronetz, D.; Feldmann, H.; Schwan, T.G. Host Competency of the Multimammate Rat Mastomys natalensis Demonstrated by Prolonged Spirochetemias with the African Relapsing Fever Spirochete Borrelia crocidurae. Am. J. Trop. Med. Hyg. 2019, 101, 1272-1275. [CrossRef]

10. Zumpt, F. Is the Multimammate Rat a Natural Reservoir of Borrelia Duttoni? Nat. Cell Biol. 1959, 184, 793-794. [CrossRef]

11. Schwan, T.G.; Anderson, J.M.; Lopez, J.E.; Fischer, R.J.; Raffel, S.J.; McCoy, B.N.; Safronetz, D.; Sogoba, N.; Maïga, O.; Traoré, S.F. Endemic Foci of the Tick-Borne Relapsing Fever Spirochete Borrelia crocidurae in Mali, West Africa, and the Potential for Human Infection. PLoS Negl. Trop. Dis. 2012, 6, e1924. [CrossRef]

12. Green, C.A.; Gordon, D.H.; Lyons, N.F. Biological Species in Praomys (Mastomys) Natalensis (Smith), a Rodent Carrier of Lassa Virus and Bubonic Plague in Africa. Am. J. Trop. Med. Hyg. 1978, 27, 627-629. [CrossRef] [PubMed]

13. Crawford, S.E.; Patel, D.G.; Cheng, E.; Berkova, Z.; Hyser, J.M.; Ciarlet, M.; Finegold, M.J.; Conner, M.E.; Estes, M.K. Rotavirus Viremia and Extraintestinal Viral Infection in the Neonatal Rat Model. J. Virol. 2006, 80, 4820-4832. [CrossRef]

14. Kesavalu, L.; Sathishkumar, S.; Bakthavatchalu, V.; Matthews, C.; Dawson, D.; Steffen, M.; Ebersole, J.L. Rat Model of Polymicrobial Infection, Immunity, and Alveolar Bone Resorption in Periodontal Disease. Infect. Immun. 2007, 75, 1704-1712. [CrossRef]

15. Wang, G.; Ojaimi, C.; Wu, H.; Saksenberg, V.; Iyer, R.; Liveris, D.; McClain, S.A.; Wormser, G.P.; Schwartz, I. Disease severity in a murine model of lyme borreliosis is associated with the genotype of the infecting Borrelia burgdorferi sensu stricto strain. J. Infect. Dis. 2002, 186, 782-791. [CrossRef]

16. Loria-Cervera, E.N.; Andrade-Narvaez, F.J. Animal models for the study of leishmaniasis immunology. Revista do Instituto de Medicina Tropical de São Paulo 2014, 56, 1-11. [CrossRef]

17. Yun, N.E.; Ronca, S.; Tamura, A.; Koma, T.; Seregin, A.V.; Dineley, K.T.; Miller, M.; Cook, R.; Shimizu, N.; Walker, A.G.; et al. Animal Model of Sensorineural Hearing Loss Associated with Lassa Virus Infection. J. Virol. 2016, 90, 2920-2927. [CrossRef]

18. Goicochea, M.A.; Zapata, J.C.; Bryant, J.; Davis, H.; Salvato, M.S.; Lukashevich, I.S. Evaluation of Lassa virus vaccine immunogenicity in a CBA/J-ML29 mouse model. Vaccine 2012, 30, 1445-1452. [CrossRef]

19. Zhu, J.; Yamane, H.; Paul, W.E. Differentiation of Effector CD4 T Cell Populations. Annu. Rev. Immunol. 2010, $28,445-489$. [CrossRef]

20. Battegay, M.; Moskophidis, D.; Rahemtulla, A.; Hengartner, H.; Mak, T.W.; Zinkernagel, R.M. Enhanced establishment of a virus carrier state in adult CD4+ T-cell-deficient mice. J. Virol. 1994, 68, 4700-4704. [CrossRef] 
21. Matloubian, M.; Concepcion, R.J.; Ahmed, R. CD4+ T cells are required to sustain CD8+ cytotoxic T-cell responses during chronic viral infection. J. Virol. 1994, 68, 8056-8603. [CrossRef]

22. Demers, K.R.; Reuter, M.A.; Betts, M.R. CD8+T-cell effector function and transcriptional regulation during HIV pathogenesis. Immunol. Rev. 2013, 254, 190-206. [CrossRef]

23. Darrah, P.A.; Patel, D.T.; De Luca, P.M.; Lindsay, R.W.B.; Davey, D.F.; Flynn, B.J.; Hoff, S.T.; Andersen, P.; Reed, S.G.; Morris, S.L.; et al. Multifunctional TH1 cells define a correlate of vaccine-mediated protection against Leishmania major. Nat. Med. 2007, 13, 843-850. [CrossRef] [PubMed]

24. Rodrigues, V.; Cordeiro-Da-Silva, A.; LaForge, M.; Ouaissi, A.; Akharid, K.; Silvestre, R.; Estaquier, J. Impairment of T Cell Function in Parasitic Infections. PLoS Negl. Trop. Dis. 2014, 8, e2567. [CrossRef] [PubMed]

25. Schussek, S.; Trieu, A.; Apte, S.H.; Sidney, J.; Sette, A.; Doolan, D.L. Immunization with Apical Membrane Antigen 1 Confers Sterile Infection-Blocking Immunity against Plasmodium Sporozoite Challenge in a Rodent Model. Infect. Immun. 2013, 81, 3586-3599. [CrossRef]

26. Egui, A.; Ledesma, D.; Pérez-Antón, E.; Montoya, A.; Gómez, I.; Robledo, S.M.; Infante, J.J.; Vélez, I.D.; López, M.C.; Thomas, M.C. Phenotypic and Functional Profiles of Antigen-Specific CD4+ and CD8+ T Cells Associated With Infection Control in Patients With Cutaneous Leishmaniasis. Front. Cell. Infect. Microbiol. 2018, 8, 393. [CrossRef]

27. Qiu, Z.; Khairallah, C.; Sheridan, B.S. Listeria Monocytogenes: A Model Pathogen Continues to Refine Our Knowledge of the CD8 T Cell Response. Pathogens 2018, 7, 55. [CrossRef] [PubMed]

28. Thakur, A.; Mikkelsen, H.; Jungersen, G. Intracellular Pathogens: Host Immunity and Microbial Persistence Strategies. J. Immunol. Res. 2019, 2019, 1-24. [CrossRef]

29. Elsaesser, H.; Sauer, K.; Brooks, D.G. IL-21 Is Required to Control Chronic Viral Infection. Science 2009, 324, 1569-1572. [CrossRef]

30. Martin, M.D.; Badovinac, V.P. Antigen-dependent and -independent contributions to primary memory CD8 T cell activation and protection following infection. Sci. Rep. 2015, 5, 18022. [CrossRef] [PubMed]

31. Gideon, H.P.; Phuah, J.; Myers, A.J.; Bryson, B.D.; Rodgers, M.A.; Coleman, M.T.; Maiello, P.; Rutledge, T.; Marino, S.; Fortune, S.M.; et al. Variability in Tuberculosis Granuloma T Cell Responses Exists, but a Balance of Pro- and Anti-inflammatory Cytokines Is Associated with Sterilization. PLoS Pathog. 2015, 11, e1004603. [CrossRef]

32. Li, B.; Du, C.; Zhou, L.; Bi, Y.; Wang, X.; Wen, L.; Guo, Z.; Song, Z.; Yang, R. Humoral and Cellular Immune Responses to Yersinia pestis Infection in Long-Term Recovered Plague Patients. Clin. Vaccine Immunol. 2011, 19, 228-234. [CrossRef] [PubMed]

33. Boussoffara, T.; Chelif, S.; Ben Ahmed, M.; Mokni, M.; Ben Salah, A.; Dellagi, K.; Louzir, H. Immunity Against Leishmania major Infection: Parasite-Specific Granzyme B Induction as a Correlate of Protection. Front. Cell. Infect. Microbiol. 2018, 8, 397. [CrossRef]

34. Campos, T.M.; Costa, R.; Passos, S.; Carvalho, L.P. Cytotoxic activity in cutaneous leishmaniasis. Memórias Inst. Oswaldo Cruz 2017, 112, 733-740. [CrossRef] [PubMed]

35. Fahey, L.M.; Wilson, E.B.; Elsaesser, H.; Fistonich, C.D.; McGAVERN, D.B.; Brooks, D.G. Viral persistence redirects CD4 T cell differentiation toward T follicular helper cells. J. Exp. Med. 2011, 208, 987-999. [CrossRef]

36. Crotty, S. T Follicular Helper Cell Differentiation, Function, and Roles in Disease. Immunity 2014, 41, 529-542. [CrossRef] [PubMed]

37. McKisic, M.D.; Barthold, S.W. T-Cell-Independent Responses to Borrelia burgdorferi Are Critical for Protective Immunity and Resolution of Lyme Disease. Infect. Immun. 2000, 68, 5190-5197. [CrossRef]

38. Lakhal-Naouar, I.; Boussoffara, T.; Meddeb-Garnaoui, A.; Ben Achour-Chenik, Y.; Louzir, H.; Chenik, M. Cellular and Humoral Responses to Leishmania major Virulence Factors in Healed Cutaneous Leishmaniasis and Mediterranean Visceral Leishmaniasis Patients. Clin. Vaccine Immunol. 2009, 16, 956-958. [CrossRef]

39. Goncalves, R.; Christensen, S.M.; Mosser, D.M. Humoral immunity in leishmaniasis—Prevention or promotion of parasite growth? Cytokine X 2020, 2, 100046. [CrossRef]

40. Safronetz, D.; Rosenke, K.; Fischer, R.J.; LaCasse, R.A.; Scott, D.P.; Saturday, G.; Hanley, P.W.; Maiga, O.; Sogoba, N.; Schwan, T.G.; et al. Establishment of a Genetically Confirmed Breeding Colony of Mastomys natalensis from Wild-Caught Founders from West Africa. Viruses 2021, 13, 590. [CrossRef]

41. Shinohara, Y.; Tsukimoto, M. Adenine Nucleotides Attenuate Murine T Cell Activation Induced by Concanavalin A or T Cell Receptor Stimulation. Front. Pharmacol. 2018, 8, 986. [CrossRef] [PubMed]

42. Palacios, R. Concanavalin A triggers T lymphocytes by directly interacting with their receptors for activation. J. Immunol. 1982, 128, 337-342.

43. Yamamura, Y.; Tanaka, J.L.; Madyastha, K.R.; Fudenberg, H.H.; Proctor, J.W. Differences in Mitogenic Responses of Murine T Cells to Two Distinct Phytohemagglutinin (Pha) Subcomponents. Immunol. Commun. 1981, 10, 9-20. [CrossRef]

44. Ceuppens, J.L.; Baroja, M.L.; Lorre, K.; Van Damme, J.; Billiau, A. Human T cell activation with phytohemagglutinin. The function of IL-6 as an accessory signal. J. Immunol. 1988, 141, 3868-3874.

45. Katzen, D.; Chu, E.; Terhost, C.; Leung, D.Y.; Gesner, M.; Miller, R.A.; Geha, R.S. Mechanisms of human T cell response to mitogens: IL 2 induces IL 2 receptor expression and proliferation but not IL 2 synthesis in PHA-stimulated T cells. J. Immunol. 1985, 135, 1840-1845.

46. Tough, D.F.; Sun, S.; Sprent, J. T Cell Stimulation In Vivo by Lipopolysaccharide (LPS). J. Exp. Med. 1997, 185, 2089-2094. [CrossRef] 
47. McAleer, J.P.; Vella, A.T. Understanding how lipopolysaccharide impacts CD4 T cell immunity. Crit. Rev. Immunol. 2008, 28, 281-299.

48. Vogel, S.N.; Hilfiker, M.L.; Caulfield, M.J. Endotoxin-induced T lymphocyte proliferation. J. Immunol. 1983, 130, 1774-1779. [PubMed]

49. Brown, A.F.; Murphy, A.G.; Lalor, S.J.; Leech, J.M.; O’Keeffe, K.M.; Mac Aogáin, M.; O’Halloran, D.P.; Lacey, K.A.; Tavakol, M.; Hearnden, C.H.; et al. Memory Th1 Cells Are Protective in Invasive Staphylococcus aureus Infection. PLoS Pathog. 2015, 11, e1005226. [CrossRef]

50. Zhao, X.; Liu, J.; Ge, S.; Chen, C.; Li, S.; Wu, X.; Feng, X.; Wang, Y.; Cai, D. Saikosaponin A Inhibits Breast Cancer by Regulating Th1/Th2 Balance. Front. Pharmacol. 2019, 10, 624. [CrossRef]

51. Benihoud, K.; Esselin, S.; Descamps, D.; Jullienne, B.; Salone, B.; Bobé, P.; Bonardelle, D.; Connault, E.; Opolon, P.; Saggio, I.; et al. Erratum: Respective roles of TNF- $\alpha$ and IL- 6 in the immune response-elicited by adenovirus-mediated gene transfer in mice. Gene Ther. 2007, 14, 551. [CrossRef]

52. Schroder, K.; Hertzog, P.J.; Ravasi, T.; Hume, D.A. Interferon- $\gamma$ : An overview of signals, mechanisms and functions. J. Leukoc. Biol. 2003, 75, 163-189. [CrossRef]

53. Westermann, J.; van Lessen, A.; Schlimper, C.; Baskaynak, G.; le Coutre, P.; Dörken, B.; Pezzutto, A. Simultaneous cytokine analysis by cytometric bead array for the detection of leukaemia-reactive T cells in patients with chronic myeloid leukaemia. $\mathrm{Br}$. $\mathrm{J}$. Haematol. 2006, 132, 32-35. [CrossRef]

54. Karlsson, A.C.; Martin, J.N.; Younger, S.R.; Bredt, B.M.; Epling, L.; Ronquillo, R.; Varma, A.; Deeks, S.G.; McCune, J.M.; Nixon, D.F.; et al. Comparison of the ELISPOT and cytokine flow cytometry assays for the enumeration of antigen-specific T cells. $J$. Immunol. Methods 2003, 283, 141-153. [CrossRef]

55. Morgan, E.; Varro, R.; Sepulveda, H.; Ember, J.A.; Apgar, J.; Wilson, J.; Lowe, L.; Chen, R.; Shivraj, L.; Agadir, A.; et al. Cytometric bead array: A multiplexed assay platform with applications in various areas of biology. Clin. Immunol. 2004, 110, 252-266. [CrossRef]

56. Hardin, A.; Nevonen, K.A.; Eckalbar, W.L.; Carbone, L.; Ahituv, N. Comparative Genomic Characterization of the Multimammate Mouse Mastomys coucha. Mol. Biol. Evol. 2019, 36, 2805-2812. [CrossRef]

57. Masopust, D.; Sivula, C.P.; Jameson, S.C. Of Mice, Dirty Mice, and Men: Using Mice To Understand Human Immunology. J. Immunol. 2017, 199, 383-388. [CrossRef]

58. Rosshart, S.P.; Herz, J.; Vassallo, B.G.; Hunter, A.; Wall, M.K.; Badger, J.H.; McCulloch, J.A.; Anastasakis, D.G.; Sarshad, A.A.; Leonardi, I.; et al. Laboratory mice born to wild mice have natural microbiota and model human immune responses. Science 2019, 365, eaaw4361. [CrossRef] [PubMed]

59. Komai-Koma, M.; Gilchrist, D.S.; Xu, D. Direct recognition of LPS by human but not murine CD8+T cellsviaTLR4 complex. Eur. J. Immunol. 2009, 39, 1564-1572. [CrossRef]

60. Chien, E.J.; Chien, C.-H.; Chen, J.-J.; Wang, S.-W.; Hsieh, D.J.-Y. Bacterial lipopolysaccharide activates protein kinase C, but not intracellular calcium elevation, in human peripheral T cells. J. Cell. Biochem. 2000, 76, 404-410. [CrossRef]

61. Ulmer, A.J.; Flad, H.-D.; Rietschel, T.; Mattern, T. Induction of proliferation and cytokine production in human T lymphocytes by lipopolysaccharide (LPS). Toxicology 2000, 152, 37-45. [CrossRef]

62. Wolk, K.; Döcke, W.D.; von Baehr, V.; Volk, H.D.; Sabat, R. Impaired antigen presentation by human monocytes during endotoxin tolerance. Blood 2000, 96, 218-223. [CrossRef] [PubMed]

63. Mattern, T.; Thanhäuser, A.; Reiling, N.; Toellner, K.M.; Duchrow, M.; Kusumoto, S.; Rietschel, E.T.; Ernst, M.; Brade, H.; Flad, H.D. Endotoxin and lipid A stimulate proliferation of human T cells in the presence of autologous monocytes. J. Immunol. 1994, 153, 2996-3004.

64. O'Neil-Andersen, N.J.; Lawrence, D.A. Differential Modulation of Surface and Intracellular Protein Expression by T Cells after Stimulation in the Presence of Monensin or Brefeldin A. Clin. Vaccine Immunol. 2002, 9, 243-250. [CrossRef] [PubMed]

65. Guy, C.S.; Vignali, K.M.; Temirov, J.; Bettini, M.L.; Overacre, A.E.; Smeltzer, M.; Zhang, H.; Huppa, J.B.; Tsai, Y.-H.; Lobry, C.; et al. Distinct TCR signaling pathways drive proliferation and cytokine production in T cells. Nat. Immunol. 2013, 14, 262-270. [CrossRef] [PubMed] 